\title{
Clostridium difficile Toxin A Upregulates Bak Expression through PGE2 Pathway in Human Colonocytes
}

\author{
Young Ha Kim and Ho Kim* \\ Division of Life Science and Chemistry, College of Natural Science, Daejin University, Pocheon 487-711, Republic of Korea
}

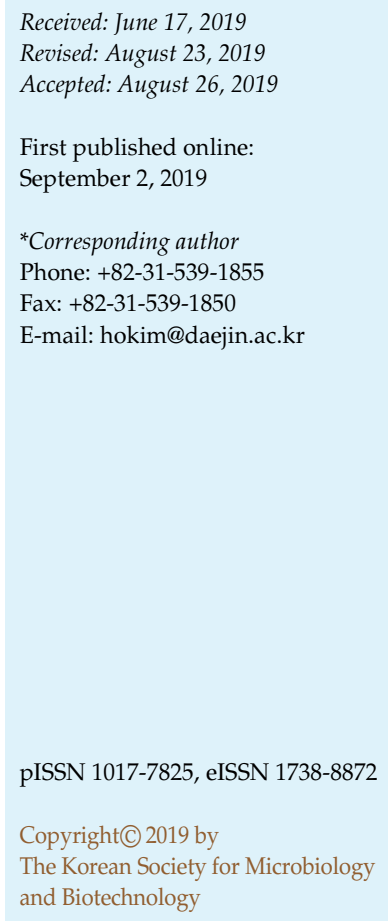

\begin{abstract}
Clostridium difficile toxin A is known to cause colonic epithelial cell apoptosis, which is considered the main causative event that triggers inflammatory responses in the colon, reflecting the concept that the essential role of epithelial cells in the colon is to form a physical barrier in the gut. We previously showed that toxin A-induced colonocyte apoptosis and subsequent inflammation were dependent on prostaglandin $\mathrm{E} 2\left(\mathrm{PGE}_{2}\right)$ produced in response to toxin A stimulation. However, the molecular mechanism by which $\mathrm{PGE}_{2}$ mediates cell apoptosis in toxin A-exposed colonocytes has remained unclear. Here, we sought to identify the signaling pathway involved in toxin A-induced, $\mathrm{PGE}_{2}$-mediated colonocyte apoptosis. In non-transformed NCM460 human colonocytes, toxin A exposure strongly upregulated expression of Bak, which is known to form mitochondrial outer membrane pores, resulting in apoptosis. RT-PCR analyses revealed that this increase in Bak expression was attributable to toxin A-induced transcriptional upregulation. We also found that toxin A upregulation of Bak expression was dependent on $\mathrm{PGE}_{2}$ production, and further showed that this effect was recapitulated by an Prostaglandin E2(PGE2) receptor-1 receptor agonist, but not by agonists of other EP receptors. Collectively, these results suggest that toxin A-induced cell apoptosis involves $\mathrm{PGE}_{2}$-upregulation of Bak through the EP1 receptor.
\end{abstract}

Keywords: Clostridium difficile, toxin A, epithelial cells, apoptosis, prostaglandin E2 (PGE2), Bak, Bax, EP1 receptor

\section{Introduction}

Clostridium difficile toxin $\mathrm{A}$, the main causative factor of pseudomembranous colitis, causes apoptosis of epithelial cells in the gut [1-7]. This apoptotic response follows inflammatory responses in the gut and is thought to result from the massive loss of barrier function, reflecting the fact that gut epithelial cells form a physical barrier that normally prohibits exposure of luminal pathogens to the interior of the body [1, 2, 4-6]. Indeed, numerous studies have investigated toxin A-induced cell apoptosis and underlying mechanisms [1-7]. For example, toxin Ainduced production of prostaglandin E2 $\left(\mathrm{PGE}_{2}\right)$ causes colonocyte apoptosis through interactions of Fas and Fas ligand (FasL) [1]. Toxin A also causes cell apoptosis through G2-M cell-cycle arrest in association with upregulation of p21 [2]. In addition, toxin A-induced inactivation of Rho proteins (Rho, Rac, cdc42) not only causes cytoskeletal disaggregation, it also strongly promotes cell apoptosis [8]. However, the molecular mechanism responsible for toxin A-induced cell apoptosis remains to be elucidated.

$\mathrm{PGE}_{2}$ has long been known as an essential mediator of inflammatory responses [9-12]. However, a number of studies have also reported that $\mathrm{PGE}_{2}$ is capable of inducing cell apoptosis [1, 13-15]. Microinjection of $\mathrm{PGE}_{2}$ induces apoptosis in human colonocytes [13]. $\mathrm{PGE}_{2}$ has also been shown to trigger apoptosis in $\mathrm{T}$ lymphocytes [16], and mediates neuroprotection and neurotoxicity [14]. Notably, $\mathrm{PGE}_{2}$ has been reported to act through EP2/EP4 prostanoid receptors to play a role in apoptosis in fibroblasts [15]. Our recent work further showed that $\mathrm{PGE}_{2}$ released from toxin A-exposed human colonocytes is critical for toxin Ainduced cell apoptosis [1].

BCL-2 homologous antagonist/killer (Bak) and Bax are 
critical members of the BCL-2 family involved in the regulation of apoptosis [17-21]. A marked increase in Bak accelerates apoptosis induced by growth factor deprivation in lung cancer and breast cancer cells [19]. Indeed, it is known that Bak expression levels in epithelial cells of the apical region of villi, where turnover rate is high, are higher than those in stem cells of the cryptic region [18, 22]. In contrast, it has also been shown that Bak expression is low in gastric cancer [17]. Collectively, these results underscore the key role of Bak in apoptosis in various cell systems.

In the current study, we examined the possible involvement of Bak in responses of NCM460 human colonocytes and a mouse ileitis model to toxin A exposure. Additionally, we determined whether $\mathrm{PGE}_{2}$ released from colonocytes exposed to toxin A is involved in toxin A-induced Bak upregulation. Our findings may aid in understanding how toxin A causes cell apoptosis in epithelial cells of the gut.

\section{Material and Methods}

\section{C. difficile Toxin A Preparation}

C. difficile VPI strain 10463 was cultured in brain heart infusion broth (Becton Dickinson, USA) under anaerobic conditions at $37^{\circ} \mathrm{C}$. After centrifugation at $8,000 \times g$ for $10 \mathrm{~min}$ and filtration through a $0.45-\mu \mathrm{m}$ membrane filter (Millipore Corp., USA), the culture supernatant was concentrated to $50 \mathrm{ml}$ by ultrafiltration at $4^{\circ} \mathrm{C}$, using an XM100 membrane filter (Amicon Corp., USA). The concentrated supernatant was loaded onto a DEAE-Sepharose CL6B column $(2.5$ by $10 \mathrm{~cm})$. The sample was sequentially eluted with a $300-\mathrm{ml}$ linear gradient of 0.05 to $0.25 \mathrm{M} \mathrm{NaCl}$, a $150-\mathrm{ml}$ wash with $0.3 \mathrm{M} \mathrm{NaCl}$, and a 300-ml linear gradient of 0.3 to $0.6 \mathrm{M}$ $\mathrm{NaCl}$, all in $50 \mathrm{mM}$ Tris-hydrochloride buffer ( $\mathrm{pH}$ 7.5). The flow rate was $60 \mathrm{ml} / \mathrm{h}$ (gravity) at $4^{\circ} \mathrm{C}$. The fractions containing the highest cytotoxic titers were dialyzed against 1 liter of $0.01 \mathrm{M}$ sodium acetate buffer ( $\mathrm{pH} 5.5$ ) at $4^{\circ} \mathrm{C}$ for $24 \mathrm{~h}$. The dialysate was centrifuged at $169 \times \mathrm{g}$ for $10 \mathrm{~min}$, the precipitate was solubilized in $10 \mathrm{ml}$ of $50 \mathrm{mM}$ Tris-hydrochloride $(\mathrm{pH} 7.5)$ containing $0.05 \mathrm{M}$ $\mathrm{NaCl}$, and the solution was filter sterilized. The purity of the obtained toxin A was assessed by gel electrophoresis, which confirmed the expected molecular mass of $307 \mathrm{kDa}$ [23].

\section{Reagents}

The following compounds were purchased from Cayman Chemical (Ann Arbor): 17-phenyl trinor PGE2 (EP1 agonist), butaprost (EP2 agonist), 11-deoxy PGE1 (EP2/4 agonist), sulprostone (EP1/3 agonist) and PGE2 neutralizing antibody [1]. The specific COX-2 inhibitor NS-398 was from Calbiochem (USA), and PGE2 was from Sigma-Aldrich (USA). The polyclonal antibody for Bax was from Santa Cruz Biotechnology (USA). Antibody against Bak was from Cell Signaling Technology (USA). Antibody against $\beta$ actin was from Sigma-Aldrich (USA). The phospholipase C (PLC) inhibitor (U-73122) and the protein kinase C (PKC) inhibitor (GF109203X) were from Calbiochem (USA). The nontransformed NCM460 human colonocytes and the culture medium M3D were obtained from INCELL Corporation (USA) [3].

\section{Immunoblot Analysis}

Human colonocytes were washed with cold PBS, then lysed in buffer (150 mM NaCl, 50 mM Tris- $\mathrm{HCl}$ [pH 8.0], 5 mM EDTA, 1\% Nonidet P-40) and equal amounts of protein were fractionated on SDS-polyacrylamide gels. Antigen-antibody complexes were detected with LumiGlo reagent (New England Biolabs Inc.) [7].

\section{C. difficile Toxin A-Induced Acute Enteritis in Mice}

Mice were anesthetized by intraperitoneal injection of sodium pentobarbital $(50 \mathrm{mg} / \mathrm{kg})$. Ileal loops $(3 \mathrm{~cm})$ were prepared by silk ligation and lumenally injected with phosphate-buffered saline (PBS) alone or toxin A ( $3 \mathrm{nM})$ plus PBS. After $4 \mathrm{~h}$, mice were sacrificed and ileal loop tissues were collected. The inflammation levels were evaluated by first washing the ileal loops with cold PBS, homogenizing them in cold PBS, and then testing the supernatants for mouse IL-6 levels using a specific ELISA (enzymelinked immunosorbent assay) kit (R\&D Systems, USA). Immunoassays were also performed on total proteins isolated from these tissues using specific anti-BAK and anti-BAX antibodies; an anti$\beta$-actin antibody was used as a loading control in these experiments. All experimental protocols involving animals were approved by the Animal Care and Use Committee of Daejin University (ACUC, Korea) [3].

\section{Real-Time Quantitative PCR and Semi-Quantitative RT-PCR}

Total mRNA was isolated from cells using RNeasy Mini Kits (Qiagen, Germany), according to the manufacturer's protocol. An RNase-Free DNase Set (Qiagen) was used to remove genomic DNA contamination. Total RNA $(0.3 \mu \mathrm{g}$ in a $20-\mu \mathrm{l}$ reaction volume) was reverse-transcribed using SuperScript II Reverse Transcriptase (Invitrogen, UK) in the presence of oligo-dT primer (Invitrogen). The primers were as follows: human Bak, forward 5'CATCAACCGACGCTATGACTC-3' and reverse 5'-GTCAGGCCA TGCTGGTAGAC-3'; human Bax, forward 5'-CTGCAGAGGATG ATTGCCG-3' and reverse 5'-TGCCACTCGGAAAAAGACCT-3'; and human cyclophilin A (PPIA), forward 5'-TCATCTGCACTG CCAAGACTG-3' and reverse 5'-CATGCCTTCTTTCACTTTGCC$3^{\prime}$. Real-time quantitative PCR reactions were performed using a Corbett Rotor-Gene 3000 with a QuantiTect SYBR Green PCR Kit (Qiagen). Samples were run in duplicate, and the amounts of Bak and Bax transcripts were normalized against those of PPIA. Semiquantitative RT-PCR was conducted as described by Nakayama et al. [24]. cDNA was amplified with Taq polymerase (PerkinElmer Life Sciences) using specific primers for human Bak (502 bp; forward 5'-CTGCCCTCTGCTTCTGA-3' and reverse 5'-CGTTCA GGATGGGACCA- $3^{\prime}$ ) and $\beta$-actin. The amplified PCR products were fractionated on a $2 \%$ agarose gel and visualized by ethidium bromide staining [3]. 


\section{Statistical Analysis}

Results are presented as mean values \pm SEM. Data were analyzed using the SIGMA-STAT professional statistics software program (Jandel Scientific Software, USA). Analyses of variance with protected $t$ test were used for intergroup comparisons [25].

\section{Results and Discussion}

\section{C. difficile Toxin A Increases the Proapoptotic Protein Bak in Human Colonocytes}

Many studies, including by our group, have shown that C. difficile toxin A causes gut epithelial cell apoptosis in association with barrier dysfunction, thereby triggering gut inflammation [1-6]. However, the molecular mechanism underlying toxin A-induced gut epithelial cell apoptosis still remains unknown. Since Bak is associated with cell apoptosis [17-19, 21], we examined Bak expression levels in human colonocytes exposed to toxin A. To this end, we incubated non-transformed NCM460 human colonocytes [3] with different concentrations of purified toxin A for $6 \mathrm{~h}$. As shown in Fig. 1A, toxin A induced expression of Bak protein; this effect was concentration-dependent between concentrations of 0.1 and $3 \mathrm{nM}$, and was maximal at $3 \mathrm{nM}$. However, toxin A had no effect on the expression of Bax, another apoptosis inducer [20]. To confirm that toxin A induces Bak expression in intact mice, we prepared ileal loops of mouse and injected them with purified toxin $\mathrm{A}$ $(3 \mathrm{nM})$. After $4 \mathrm{~h}$, levels of the proinflammatory cytokine interleukin [23]-6 were markedly upregulated in ileal extracts from mice injected with toxin A [26] compared with those from control mice injected with PBS (Fig. 1B, upper). Bak was also weakly expressed in control mouse ileum, but was robustly increased after toxin A exposure (Fig. 1B, lower), with results similar to those obtained in cultured colonocytes (Fig. 1A). Moreover, Bax expression was not changed in the ileum of mice injected with toxin $\mathrm{A}$, as the results were also similar to those for NCM460 cells exposed to toxin A. These results indicate that the epithelial cell apoptosis associated with toxin A-induced ileitis is associated with Bak expression, but not Bax expression.

Toxin A is known to cause a marked release of cytochrome c from mitochondria during colonocyte apoptosis, which in turn activates downstream pathways involving caspases, a pathway known as mitochondrial apoptosis [2]. Because cytochrome c release from the mitochondria inner space to the cytosol is dependent on outer membrane pore formation $[27,28]$, and Bak and Bax generate the outer membrane pores through which cytochrome c is released [21, 29, 30], our demonstration that toxin A markedly upregulates
A

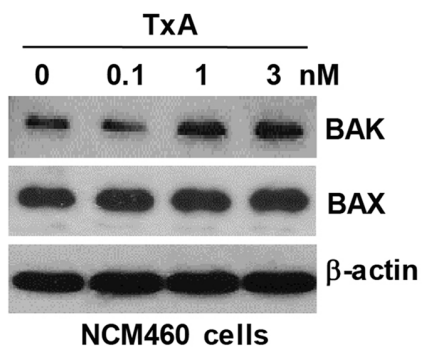

B
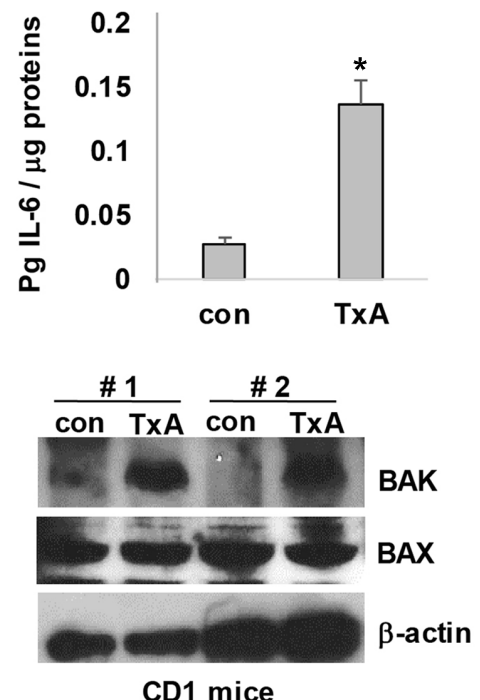

Fig. 1. C. difficile toxin A induces Bak expression in human colonocytes.

(A) Non-transformed NCM460 human colonocytes were incubated with different concentrations ( 0 to $3 \mathrm{nM}$ ) of toxin A. After $6 \mathrm{~h}$, cells were lysed and total protein was fractionated on $10 \%$ SDSpolyacrylamide gels and probed with antibodies against Bak, Bax, or $\beta$-actin. The presented results are representative of three independent experiments. (B, upper) Ileal loops of mice ( $n=6$ mice/group) were prepared and then exposed to toxin $A(3 \mathrm{nM})$ for $4 \mathrm{~h}$. The concentration of IL-6 was measured by ELISA. Data are presented as means \pm SEM (error bars) from three independent experiments performed in triplicate $\left({ }^{*}, p<0.05\right)$. (B, lower) Mucosal extracts were resolved on $10 \%$ polyacrylamide gel and probed with the indicated antibodies. Data shown are representative of five separate samples.

expression of Bak, but not Bax, in both a human colonocyte cell line and the gut of mouse strongly suggests that toxin Ainduced mitochondrial apoptosis (cytochrome c release and subsequent apoptosis progression) is mediated by Bak upregulation.

\section{C. difficile Toxin A Increases Bak Transcription in Human Colonocytes}

We next assessed whether toxin A increases transcription of BAK in human colonocytes. To this end, we treated 
NCM460 cells with toxin A ( $3 \mathrm{nM})$ for 12, 24, and $36 \mathrm{~h}$, and then isolated total RNA and performed real-time RT-PCR using primers specific for human Bak and Bax. Under basal conditions, we observed weak mRNA expression of Bak and Bax in cultured colonocytes (Fig. 2A). Toxin A treatment time-dependently increased Bak mRNA by up to 12-fold, whereas it only weakly induced Bax mRNA expression. Semi-quantitative RT-PCR revealed that toxin A also markedly increased BAK mRNA expression in human colonocytes (Fig. 2B). These results suggest that the marked increase in Bak protein induced by toxin $\mathrm{A}$ is dependent on gene transcription.

The transcriptions of Bak and Bax are known to be regulated by p53 [31-33], which is also reportedly activated during the toxin A-induced apoptosis of human colonocytes [2]. Here, however, we found that toxin A increased the transcription of Bax but not Bak. These results indicate that although p53 is a main factor for the transcriptional activation of the genes encoding Bak and

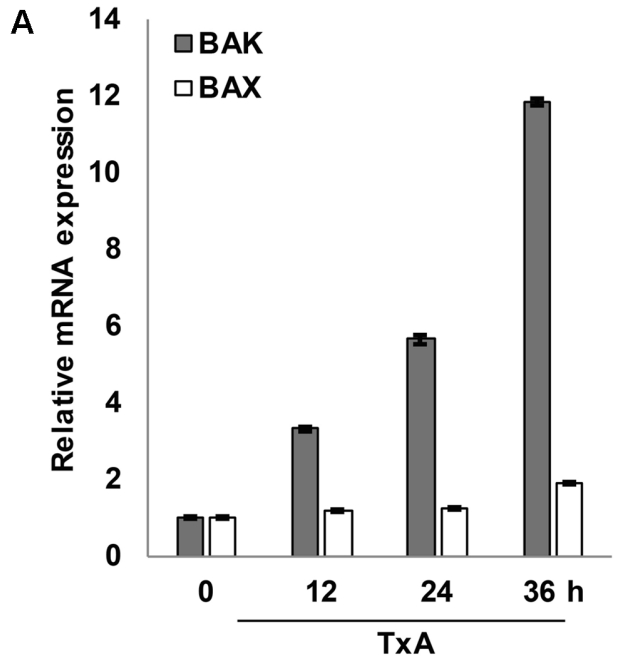

B

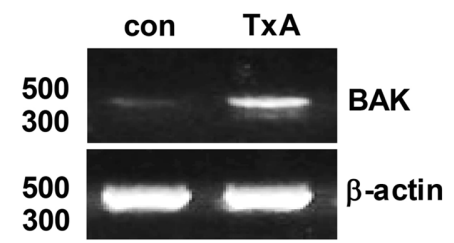

Fig. 2. Toxin A induces transcription of Bak.

(A) NCM460 cells were incubated with toxin A ( $3 \mathrm{nM}$ ) for 0,12 , 24, or $36 \mathrm{~h}$. Total RNA was isolated and the amounts of Bak transcripts were determined by quantitative RT-PCR and normalized against PPIA. (B) NCM460 cells were incubated with toxin A (3 nM) for $6 \mathrm{~h}$, and Bak mRNA expression was determined by semi-quantitative RTPCR. The presented results are representative of three independent experiments.
Bax, the maximum induction of these genes requires different co-factors. Indeed, it has been reported that p53 requires the cooperation of an Sp1-like factor to mediate the transcriptional activation of the human Bax promoter $[31,34]$. Taken together, our results show that, in NCM460 human colonocytes, toxin A activates p53 and a co-factor that is involved in the transcriptional activation of Bak but not Bax.

\section{Toxin A-Induced Bak Upregulation in Human Colonocytes} Is Mediated by a PGE 2 Pathway

We previously reported that toxin A causes marked secretion of $\mathrm{PGE}_{2}$ in human colonocytes, a pathway critical for toxin A-induced cell apoptosis [1]. Given that Bak is essential for apoptosis in various cell systems [17-19, 21], we examined whether toxin A-induced upregulation of Bak in human colonocytes was associated with extracellular $\mathrm{PGE}_{2}$ secreted by toxin A-exposed colonocytes. As shown in Fig. 3A, toxin A significantly increased Bak expression, an effect that was blocked by a $\mathrm{PGE}_{2}$ neutralizing antibody in a concentration-dependent manner. Toxin A-induced upregulation of Bak was also reduced by NS398, a selective COX-2 inhibitor $[1,3]$. These results indicate that toxin Ainduced secretion of $\mathrm{PGE}_{2}$ in colonocytes is critical for Bak induction (Fig. 3B). Because we previously found that $10 \mu \mathrm{M} \mathrm{PGE}_{2}$ induced maximal apoptosis in NCM460 cells [1], we examined whether the concentration of $\mathrm{PGE}_{2}$ used to cause apoptosis is capable of upregulating Bak expression in human colonocytes. As shown in Fig. 3C, treatment with $\mathrm{PGE}_{2}$ alone induced Bak protein expression in human colonocytes in a time-dependent manner, producing an increase in protein levels very similar to that in cells exposed to toxin $\mathrm{A}$. These results suggest that $\mathrm{PGE}_{2}$ mediates the toxin A-induced increase in Bak in human colonocytes that could trigger cytochrome c release from mitochondria and subsequent apoptosis progression. Similarly, increasing intracellular $\mathrm{PGE}_{2}$ concentration in the human colon cancer cell lines SW1116 and HCT-116 by direct microinjection was previously reported to induce apoptosis via a mechanism that was dependent on Bax upregulation, as evidenced by the resistance of Baxdeficient HCT-116 cells to $\mathrm{PGE}_{2}$-induced cell apoptosis [13]. The apparent discrepancy in Bak versus Bax involvement after $\mathrm{PGE}_{2}$ treatment among these studies reflects differences in cell type and whether $\mathrm{PGE}_{2}$ acts intracellularly [13] or extracellularly $[1,3]$. Taken together, these results suggest that upregulation of Bak or Bax, known as mitochondrial outer membrane-pore-forming proteins, may be an initial and critical event for $\mathrm{PGE}_{2}$-induced mitochondrial apoptosis 
A

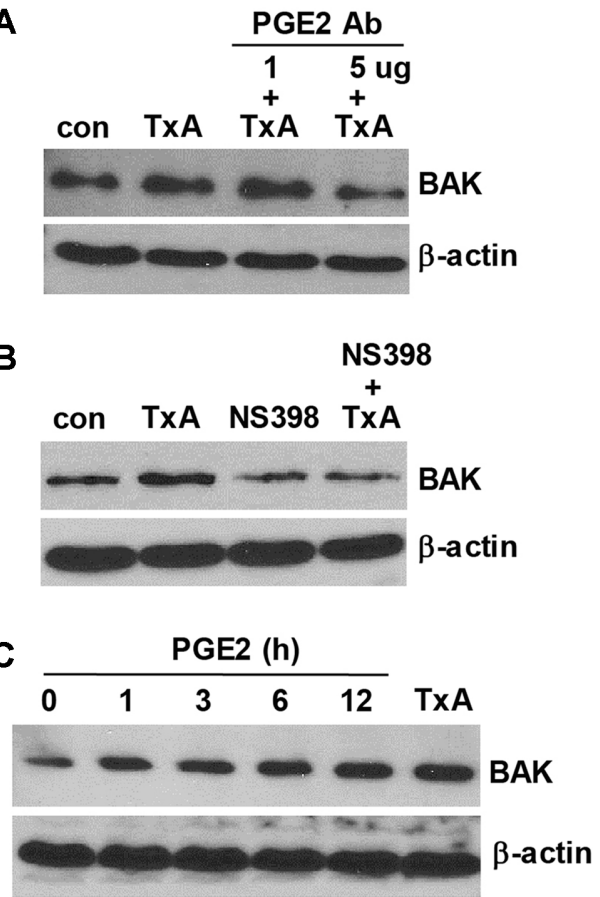

Fig. 3. $\mathrm{PGE}_{2}$ mediates toxin A-induced upregulation of Bak in human colonocytes.

Colonocytes were exposed to toxin A alone ( $3 \mathrm{nM})$ or toxin A plus $\mathrm{PGE}_{2}$ blocking antibody ( 1 to $5 \mu \mathrm{g} / \mathrm{ml}$ ) for $6 \mathrm{~h}$. Cells were lysed and total protein was fractionated on 10\% SDS-polyacrylamide gels and probed with antibodies against Bak or $\beta$-actin. The presented results are representative of three independent experiments. (B) Colonocytes were exposed to toxin A alone ( $3 \mathrm{nM}$ ), NS398, or toxin A plus NS398 $(100 \mu \mathrm{M})$ for $6 \mathrm{~h}$. (C) Colonocytes were incubated with $\mathrm{PGE}_{2}(10 \mu \mathrm{M})$. At the indicated time points, cell lysates were resolved on $10 \%$ polyacrylamide gels and probed with the indicated antibodies. Results shown are representative of three independent experiments.

in human colonocytes, a pathway that is also involved in toxin A-induced colonocyte apoptosis.

$\mathrm{PGE}_{2}$ Acts Specifically through the EP1 Receptor to Mediate Upregulation of Bak in Human Colonocytes

Our previous study showed that NCM460 human colonocytes constitutively express EP1 and EP4 receptors, but not EP2 or EP3 receptors, all of which are activated by $\mathrm{PGE}_{2}$ [1]. This study also showed that toxin A-induced colonocyte apoptosis was dependent on specific binding of $\mathrm{PGE}_{2}$ to the EP1 receptor, but not other EP receptors [1]. Therefore, we examined whether the EP1 receptor is critical for $\mathrm{PGE}_{2}$-induced upregulation of Bak in human colonocytes. To explore this, we treated NCM460 cells for $2 \mathrm{~h}$ with $\mathrm{PGE}_{2}$ or the following synthetic agonists of EP1-4 receptors [1]: 17-phenyl trinor $\mathrm{PGE}_{2}$ (EP1 agonist),
A
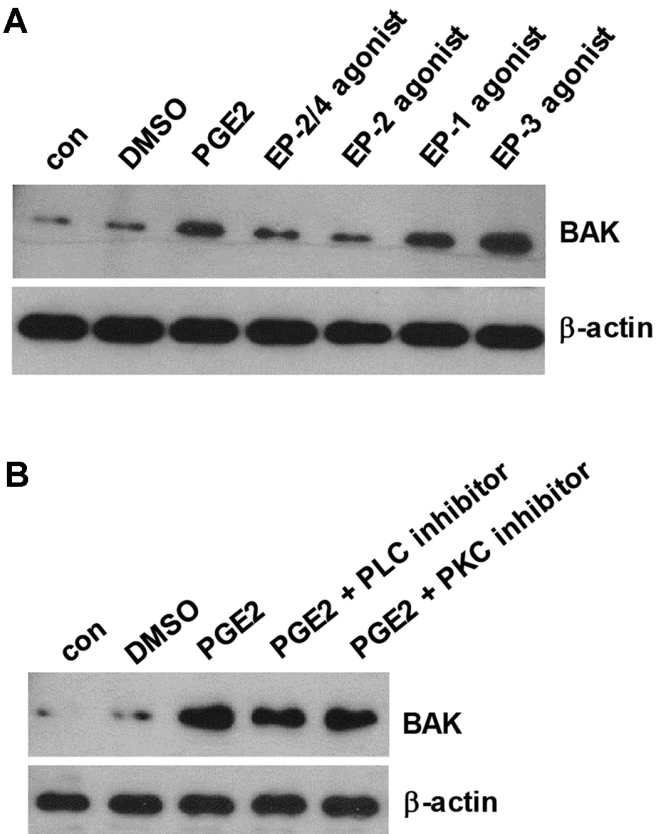

Fig. 4. EP1 mediates $\mathrm{PGE}_{2}$-induced upregulation of Bak.

(A) Colonocytes were exposed to DMSO, $10 \mu \mathrm{M} \mathrm{PGE}_{2}, 10 \mu \mathrm{M}$ 11deoxy $\mathrm{PGE}_{1}$ (EP2/4 agonist), $10 \mu \mathrm{M}$ butaprost (EP2 agonist), $5 \mu \mathrm{M}$ 17phenyl trinor $\mathrm{PGE}_{2}$ (EP1 agonist), or $10 \mu \mathrm{M}$ sulprostone (EP1/3 agonist) for $2 \mathrm{~h}$. Cell lysates were resolved on $10 \%$ polyacrylamide gels and probed with the indicated antibodies. Results shown are representative of three independent experiments (B). Colonocytes were incubated with DMSO, $\mathrm{PGE}_{2}(10 \mu \mathrm{M})$, or toxin $\mathrm{A}(3 \mathrm{nM})$ plus either PLC inhibitor (U-73122, $10 \mu \mathrm{M}$ ) or PKC inhibitor (GF109203X, $10 \mu \mathrm{M}$ ) for $2 \mathrm{~h}$. Cell lysates were resolved on $10 \%$ polyacrylamide gels and probed with the indicated antibodies. Results are representative of three separate experiments.

butaprost (EP2 agonist), sulprostone (EP1/3 agonist), and 11-deoxy $\mathrm{PGE}_{1}$ (EP2/4 agonist). As expected, the selective EP1 agonist markedly induced Bak expression in human colonocytes, producing an increase in Bak levels similar to that in cells treated with $\mathrm{PGE}_{2}$ (Fig. 4A). The EP1/3 agonist also increased Bak expression to a similar extent as the EP1 agonist. However, EP2 (butaprost) or EP2/4 (11-deoxy PGE1) agonists had no effect on Bak expression (Fig. 4A). Given that both EP1 and EP1/3 agonists induced Bak expression, we confirmed the receptor involved by examining signaling pathways for $\mathrm{PGE}_{2}$-mediated Bak induction in colonocytes. EP1 signaling is known to activate the phospholipase C (PLC) pathway through G proteins of the $G_{q / 11}$ subtype [35], leading to mobilization of intracellular calcium and activation of protein kinase $C$ (PKC) [36], whereas EP3 typically binds to a $\mathrm{G}_{\mathrm{i}}$ protein, leading to a reduction in intracellular cAMP levels [37]. We 
therefore assessed Bak expression in NCM460 cells following treatment with $\mathrm{PGE}_{2}$ alone or together with a PLC inhibitor (U-73122) or PKC inhibitor (GF109203X); we also monitored cAMP production. As shown in Fig. 4B, $\mathrm{PGE}_{2}$-induced upregulation of Bak was markedly reduced by both PLC inhibition and PKC inhibition, consistent with a role for a $G_{q / 11}$ protein. In contrast, $P_{G E}$ treatment had no effect on cAMP production in human colonocytes (data not shown).

$\mathrm{PGE}_{2}$ is known as an essential mediator of inflammatory responses [9-12], but it is also involved in cell apoptosis [1, 13-15]. The PLC and PKC pathways are key regulators for cell proliferation and the inhibition of apoptosis in many cell systems [38], but other studies have found that the PKC pathway can also be positively associated with apoptosis $[39,40]$. Moreover, PLC $\gamma 2$ has been reported to promote cell apoptosis in primary rat hepatocytes [41]. In the present study, we reveal that the EP1 receptor-activated PLC and PKC pathways are involved in the toxin Ainduced upregulation of Bak, which triggers the release of cytochrome c from mitochondria and thereby contributes to the progression of cell apoptosis. These results suggest that the toxin A-induced $\mathrm{PGE}_{2} / \mathrm{EP} 1$-mediated activation of the PLC and PKC pathways in human colonocytes does not appear to protect against cell apoptosis.

Collectively, these results indicate that toxin $\mathrm{A}$ acts through the $\mathrm{PGE}_{2} / \mathrm{EP} 1$ pathway to induce upregulation of Bak in human colonocytes, and that this pathway may be additively involved in toxin A-induced apoptotic progression and could potentially accelerate the toxin A-induced death of colonocytes.

\section{Acknowledgment}

This work was supported by the Daejin University Research Grants in 2019.

\section{Conflict of Interest}

The authors have no financial conflicts of interest to declare.

\section{References}

1. Kim H, Rhee SH, Pothoulakis C, Lamont JT. 2007. Inflammation and apoptosis in Clostridium difficile enteritis is mediated by PGE2 up-regulation of Fas ligand. Gastroenterology 133: $875-886$.

2. Kim H, Kokkotou E, Na X, Rhee SH, Moyer MP, Pothoulakis C, et al. 2005. Clostridium difficile toxin A-induced colonocyte apoptosis involves pp.53-dependent p21(WAF1/ CIP1) induction via p38 mitogen-activated protein kinase. Gastroenterology 129: 1875-1888.

3. Kim H, Rhee SH, Kokkotou E, Na X, Savidge T, Moyer MP, et al. 2005. Clostridium difficile toxin a regulates inducible cyclooxygenase-2 and prostaglandin E2 synthesis in colonocytes via reactive oxygen species and activation of p38 MAPK. J. Biol. Chem. 280: 21237-21245.

4. He D, Sougioultzis S, Hagen S, Liu J, Keates S, Keates AC, et al. 2002. Clostridium difficile toxin A triggers human colonocyte IL-8 release via mitochondrial oxygen radical generation. Gastroenterology 122: 1048-1057.

5. Kim DH, Hwang JS, Lee IH, Nam ST, Hong J, Zhang P, et al. 2016. The insect peptide CopA3 increases colonic epithelial cell proliferation and mucosal barrier function to prevent inflammatory responses in the gut. J. Biol. Chem. 291: 32093223.

6. Chumbler NM, Farrow MA, Lapierre LA, Franklin JL, Lacy DB. 2016. Clostridium difficile toxins TcdA and TcdB cause colonic tissue damage by distinct mechanisms. Infect. Immun. 84: 2871-2877.

7. Kim DH, Lee IH, Nam ST, Nam HJ, Kang JK, Seok H, et al. 2014. Effect of antisera from Clostridium difficile-infected mice on toxin-A-induced colonic epithelial cell death signaling. J. Microbiol. Biotechnol. 24: 696-703.

8. Subauste MC, Von Herrath M, Benard V, Chamberlain CE, Chuang TH, Chu K, et al. 2000. Rho family proteins modulate rapid apoptosis induced by cytotoxic $\mathrm{T}$ lymphocytes and Fas. J. Biol. Chem. 275: 9725-9733.

9. Robb CT, McSorley HJ, Lee J, Aoki T, Yu C, Crittenden S, et al. 2018. Prostaglandin E2 stimulates adaptive IL-22 production and promotes allergic contact dermatitis. J. Allergy Clin. Immunol. 141: 152-162.

10. Liang $X$, Wang $Q$, Shi J, Lokteva L, Breyer RM, Montine TJ, et al. 2008. The prostaglandin E2 EP2 receptor accelerates disease progression and inflammation in a model of amyotrophic lateral sclerosis. Ann. Neurol. 64: 304-314.

11. Huang WT, Niu KC, Chang CK, Lin MT, Chang CP. 2008. Curcumin inhibits the increase of glutamate, hydroxyl radicals and PGE2 in the hypothalamus and reduces fever during LPS-induced systemic inflammation in rabbits. Euro. J. Pharm. 593: 105-111.

12. Turull N, Queralt J. 2000. Effect of the COX-2 selective inhibitor 1-745,337 on inflammation and organ prostaglandin E2 (PGE2) levels in adjuvant arthritic rats. Inflammation 24: 533-545.

13. Lalier L, Pedelaborde F, Braud C, Menanteau J, Vallette FM, Olivier C. 2011. ncrease in intracellular PGE2 induces apoptosis in Bax-expressing colon cancer cell. BMC Cancer 11: 153.

14. Wu L, Wang Q, Liang X, Andreasson K. 2007. Divergent effects of prostaglandin receptor signaling on neuronal survival. Neurosci. Lett. 421: 253-258. 
15. Huang SK, White ES, Wettlaufer SH, Grifka H, Hogaboam CM, Thannickal VJ, et al. 2009. Prostaglandin E(2) induces fibroblast apoptosis by modulating multiple survival pathways. FASEB J. 23: 4317-4326.

16. Pica F, Franzese O, D'Onofrio C, Bonmassar E, Favalli C, Garaci E. 1996. Prostaglandin E2 induces apoptosis in resting immature and mature human lymphocytes: a c-Mycdependent and Bcl-2-independent associated pathway. J. Pharmacol. Exp. Ther. 277: 1793-1800.

17. Krajewska M, Fenoglio-Preiser CM, Krajewski S, Song K, Macdonald JS, Stemmerman G, et al. 1996. Immunohistochemical analysis of Bcl-2 family proteins in adenocarcinomas of the stomach. Am. J. Pathol. 149: 1449-1457.

18. Krajewski S, Krajewska M, Reed JC. 1996. Immunohistochemical analysis of in vivo patterns of Bak expression, a proapoptotic member of the Bcl-2 protein family. Cancer Res. 56: 2849-2855.

19. Pataer A, Fang B, Yu R, Kagawa S, Hunt KK, McDonnell TJ, et al. 2000. Adenoviral Bak overexpression mediates caspasedependent tumor killing. Cancer Res. 60: 788-792.

20. Hass R, Busche R, Luciano L, Reale E, Engelhardt WV. 1997. Lack of butyrate is associated with induction of Bax and subsequent apoptosis in the proximal colon of guinea pig. Gastroenterology 112: 875-881.

21. Westphal D, Dewson G, Czabotar PE, Kluck RM. 2011. Molecular biology of Bax and Bak activation and action. Biochimica et Biophysica Acta 1813: 521-531.

22. Kiefer MC, Brauer MJ, Powers VC, Wu JJ, Umansky SR, Tomei LD, et al. 1995. Modulation of apoptosis by the widely distributed Bcl-2 homologue Bak. Nature 374: 736-739.

23. Sullivan NM, Pellett S, Wilkins TD. 1982. Purification and characterization of toxins $\mathrm{A}$ and $\mathrm{B}$ of Clostridium difficile. Infect. Immun. 35: 1032-1040.

24. Nakayama H, Yokoi H, Fujita J. 1992. Quantification of mRNA by non-radioactive RT-PCR and CCD imaging system. Nucleic Acids Res. 20: 4939.

25. Yoon IN, Hwang JS, Lee JH, Kim H. 2019. The antimicrobial peptide CopA3 inhibits Clostridium difficile toxin a-induced viability loss and apoptosis in neural cells. J. Microbiol. Biotechnol. 29: 30-36.

26. Reimund JM, Wittersheim C, Dumont S, Muller CD, Kenney JS, Baumann R, et al. 1996. Increased production of tumour necrosis factor-alpha interleukin-1 beta, and interleukin- 6 by morphologically normal intestinal biopsies from patients with Crohn's disease. Gut 39: 684-689.

27. Martinou I, Desagher S, Eskes R, Antonsson B, Andre E, Fakan S, et al. 1999. The release of cytochrome c from mitochondria during apoptosis of NGF-deprived sympathetic neurons is a reversible event. J. Cell Biol. 144: 883-889.

28. Lim ML, Lum MG, Hansen TM, Roucou X, Nagley P. 2002. On the release of cytochrome $\mathrm{c}$ from mitochondria during cell death signaling. J. Biomed. Sci. 9: 488-506.

29. Priault M, Chaudhuri B, Clow A, Camougrand N, Manon S. 1999. Investigation of bax-induced release of cytochrome $\mathrm{C}$ from yeast mitochondria permeability of mitochondrial membranes, role of VDAC and ATP requirement. Euro. J. Biochem. 260: 684-691.

30. Heimlich G, McKinnon AD, Bernardo K, Brdiczka D, Reed JC, Kain R, et al. 2004. Bax-induced cytochrome c release from mitochondria depends on alpha-helices-5 and -6. Biochem. J. 378: 247-255.

31. Thornborrow EC, Manfredi JJ. 2001. The tumor suppressor protein p53 requires a cofactor to activate transcriptionally the human BAX promoter. J. Biol. Chem. 276: 15598-15608.

32. Baltaziak M, Koda M, Wincewicz A, Sulkowska M, Kanczuga-Koda L, Sulkowski S. 2009. Relationships of P53 and Bak with EPO and EPOR in human colorectal cancer. Anticancer Res. 29: 4151-4156.

33. Fortuno MA, Zalba G, Ravassa S, D'Elom E, Beaumont FJ, Fortuno A, et al. 1999. p53-mediated upregulation of BAX gene transcription is not involved in Bax-alpha protein overexpression in the left ventricle of spontaneously hypertensive rats. Hypertension 33: 1348-1352.

34. Kong X, Xu P, Cai WJ, Wang HG, Li BB, Huang GL, et al. 2018. ZBP-89 and Sp1 contribute to Bak expression in hepatocellular carcinoma cells. BMC Cancer 18: 419.

35. Asboth G, Phaneuf S, Europe-Finner GN, Toth M, Bernal AL. 1996. Prostaglandin E2 activates phospholipase C and elevates intracellular calcium in cultured myometrial cells: involvement of EP1 and EP3 receptor subtypes. Endocrinology 137: 2572-2579.

36. Rojas A, Gueorguieva P, Lelutiu N, Quan Y, Shaw R, Dingledine R. 2014. The prostaglandin EP1 receptor potentiates kainate receptor activation via a protein kinase C pathway and exacerbates status epilepticus. Neurobiol. Dis. 70: 74-89.

37. Irie A, Sugimoto $Y$, Namba T, Asano T, Ichikawa A, Negishi M. 1994. The C-terminus of the prostaglandin-E-receptor EP3 subtype is essential for activation of GTP-binding protein. Euro. J. Biochem. 224: 161-166.

38. Soares AS, Costa VM, Diniz C, Fresco P. 2015. Inosine strongly enhances proliferation of human C32 melanoma cells through PLC-PKC-MEK1/2-ERK1/2 and PI3K pathways. Basic Clin. Pharmacol. Toxicol. 116: 25-36.

39. Panaretakis T, Laane E, Pokrovskaja K, Bjorklund AC, Moustakas A, Zhivotovsky B, et al. 2005. Doxorubicin requires the sequential activation of caspase-2, protein kinase Cdelta, and c-Jun NH2-terminal kinase to induce apoptosis. Mol. Biol. Cell 16: 3821-3831.

40. Meinhardt G, Roth J, Totok G. 2000. Protein kinase C activation modulates pro- and anti-apoptotic signaling pathways. Euro. J. Cell Biol. 79: 824-833.

41. Chen X, Lv Q, Ma J, Liu Y. 2018. PLC gamma2 promotes apoptosis while inhibits proliferation in rat hepatocytes through PKCD/JNK MAPK and PKCD/p38 MAPK signalling. Cell Prolif. 51: e12437. 